UDC: 327.5

\title{
Георгій Григоров
}

Дніпровська академія неперервної освіти

\section{Використання засобів масової інформації як інструментів освітнього процесу через навички критичного мислення}

Стрімкий розвиток інформаційних і комунікаційних технологій надає доступ сучасного суспільства до найрізноманітніших джерел інформації, які дають можливість споживати більшу кількість, ідей, пропозицій, посилань і рішень, що лунають з боку засобів масової інформації, соціальних мереж, блогерів, лідерів громадських думок.

Якщо ви звертаєтеся до засобів масової інформації, одне з питань, яке стоїть на порядку денному і мотивує їх вивчення з точки зору освіти - це їхня здатність домінувати і маніпулювати думкою користувачів. Сьогодні, як ніколи раніше, необхідно увійти в світ комунікацій з критичної позиції, яка включає в себе рефлексію і скептицизм.

Аналіз процесів в освітньому просторі показує, що з появою і розвитком мас-медіа виникає життєва необхідність їх використання у навчанні дітей та дорослих. Тому ми вважаємо, що необхідно провести серйозне, складне, послідовне і раціональне обговорення проблеми критичного споживання інформації.

Наше теоретичне дослідження спрямоване на аналіз ролі засобів масової інформації як інструменту навчання та виховної діяльності, а також, значення навичок критичного мислення для використання різних джерел інформації в рамках освітнього простору.

Вчителям іучнямпотрібні орієнтири -практичні, відображені і сформульовані навколо процесів побудови освітньої діяльності. Однією з ключових функцій школи в кінці століття повинна стати допомога учням усвідомлювати роль засобів масової інформації в їх власному соціальному житті; їх знайомство з технічними і символічними механізмами, за допомогою яких засоби масової інформації спокушають глядача; пропаганда адекватних ціннісних критеріїв, які вчать учнів бачити і обирати продукти більш високої культурної якості.

Для формування сучасної соціально компетентної особистості з високим рівнем культури та громадянської відповідальності потрібно об'єднання зусиль не тільки професійних педагогів, а й спеціалістів мас-медіа, громадських організацій, батьків і, звичайно, самих учнів.

Ключові слова: засоби масової інформації, освіта, критичне спожсивання, комунікація, сочіальна компетентність

George Grigorov

Dnipro Academy of Continuing Education

\section{Using the media as tools for the educational process through critical thinking skills}

The rapid development of information and communication technologies gives modern society access to a variety of information sources that enable the consumption of more ideas, suggestions, references and solutions, coming from the media, social media, bloggers and opinion leaders.

If you turn to the media, one of the issues that is on the agenda and motivates their study from an educational perspective is their ability to dominate and manipulate the opinions of their users. Today, more than ever, it is necessary to enter the world of communications from a critical stance that includes reflection and skepticism.

Analysis of processes in the educational space shows that with the emergence and development of mass media there is a vital need for their use in the education of children and adults. Therefore, we believe that a serious, sophisticated, consistent and rational discussion of the problem of critical information consumption is necessary.

The aim of the theoretical research is to analyze the role of media as a tool for learning and educational activities, as well as the importance of critical thinking skills for the use of different information sources within the educational space.

Teachers and students need practical, reflective and articulated around the processes of building educational activities guidelines. One of the key functions of the school at the end of the century should be to help students become aware of the role of the media in their own social life; to raise their familiarity with the technical and symbolic mechanisms by which the media seduce the viewer; to promote adequate value criteria, to teach children to see and choose products of higher cultural quality.

To form a modern socially competent person with a high level of culture and civic responsibility it is necessary to combine the efforts of not only professional teachers, but also specialists of mass media, public organizations, parents and, of course, the students themselves.

Keywords: media, education, critical thinking, communication, social competence 
$\mathrm{C}$ трімкий розвиток інформаційних i комунікаційних технологій (IКТ) надає доступ сучасного суспільства до найрізноманітніших джерел інформації, які дають можливість споживати більшу кількість, ідей, пропозицій, послань і рішень, що лунають із боку засобів масової інформації, соціальних мереж, блогерів та лідерів громадських думок. Присутність цих засобів масової інформації стає все більш очевидною в інформаційному суспільстві, i, в той же час, вони стали каналами комунікації, через які ми отримуємо цінності, стереотипи, тенденції, які не завжди обгрунтовані, адекватні та корисні для суспільства.

Якщо ви звертаєтеся до засобів масової інформації, одне 3 питань, яке стоїть на порядку денному і мотивує їх вивчення 3 точки зору освіти, це їхня здатність домінувати i маніпулювати думкою користувачів. Сьогодні, як ніколи раніше, необхідно увійти в світ комунікацій 3 критичною позицією, яка включає в себе рефлексію і скептицизм, що змушують нас постійно сумніватися в ролі, яку відіграють засоби масової інформації.

Наряду 3 тим, як ми говоримо про природність процесу обміну інформацією, варто відзначити, що існує стурбованість 3 приводу впливу на дітей телебачення, знань, отриманих за допомогою машин, впливу комп'ютерних ігор, фільмів i мультфільмів, в яких пропагується насильство. Ми спекулюємо їхнім впливом на моральність i передбачувану втрату фізичної людської взаємодії. Комп'ютерні ігри і віртуальне спілкування піддавалися широкої критиці за своє насильство (Пензєв, 2012), насильство, яке в багатьох випадках не $\epsilon$ репрезентативним для фактичного насильства. 3 цього питання в 1980-і роки було проведено роботу 3 аналізу телебачення, в результаті якої прийшли до висновку, що телевізійні новини, як правило, пропонують в десять разів більше насильства, ніж в реальному житті бачать люди, які дивилися їх. Ця ідея, разом з іншою, що в перші 18 років життя середньостатистичний молодий чоловік витрачає більше часу на перегляд телевізора, ніж на будь-яку іншу діяльність, крім сну, наводить на думку про те, що необхідно взяти на себе виховну роль щодо досвіду, опосередкованого через медіа. Формування установок і думок про соціальний мир - це центральна ідея «культивації переконань», яку було розроблено американським дослідником ЗМІ Георгом Гербнера. Головна ідея полягає в тому, що телебачення це основний соціальний інститут сучасного суспільства. Вплив телебачення полягає не стільки в передачі специфічних установок і думок, скільки в їх культивації.

Розгляд цієї проблеми безпосередньо переноситься в освітню сферу. Стрімкий розвиток і зростання об'єму віртуальної реальності вимагає необхідного підвищення рівня життєвого досвіду. Ще в кінці минулого сторіччя було проведено опитування серед дітей в США про їхні стосунки 3 природою i виявилось, що, незважаючи на те, що сучасна молодь, як правило, краще інформована про глобальні екологічні проблеми, вони також, як правило, мають дуже мало безпосереднього контакту 3 природою. Вони обміняли віртуальний досвід на реальний фізичний контакт з природою. Дослідження показало, що діти часто більше прислухаються до ритмів машин, ніж до ритмів природи (Swartz, \& Hatcher, 1996). Вечірні новини перетворили інформацію в розвагу, а серйозну, послідовну, раціональну i складну експозицію відсунуто на другий план. Наше розуміння контексту, прагнення аналізувати зміст отриманої інформації в рамках соціального етноцентризму, наші враження, що випливають з безпосередньої взаємодії ми замінюємо на синтетично виведені віртуальні значення, тим самим відокремлюючи себе від нашої власної спадщини та почуття спільності, від наших власних визначень.

Bce частіше останнім часом вагому частину новинного контенту представляють інтернет-ресурси. Зростання ролі інтернету й цифрових медіа впливає на споживання ЗМІ і в Україні. Про це свідчить збільшення показників читання новин за 2018 р. у порівнянні з 2017 р., а саме, користування новинними сайтами зросло на $6 \%$, а соціальними мережами на $8 \%$ (Za rezultatami schorichnogo opytuvannja, 2018).

В інформаційному суспільстві користувачів глобальної мережі оточує 
повсюдний інформаційний шум. Частково його створюють i медіа, поширюючи неперевірені новини, клікбейтні заголовки та відверті фейки, аби лише збільшити кількість заходів на сайт. Читачі сподіваються, що засоби масової інформації, яким вони довіряють, ретельно перевіряють дані, які поширюють, та на практиці це не завжди так. Часто медіа не свідомі щодо того, яка велика відповідальність покладена на них, адже ЗМІ відіграють важливу роль у формуванні аудиторії навичок медіаграмотності у споживачів інформації (Ладика, 2018).

Розвиток інформаційних технологій забезпечує практично цілодобове використання медіапростору для маніпуляцій суспільною думкою. Такий стан речей формує сталі інформаційнопсихологічні загрози i, коли вони накладаються на грунт широкого психічного розладу населення, то виникають серйозні наслідки, які катастрофічно впливають на інформаційно-психологічну безпеку суспільства та держави (Нерсессян, 2018).

Аналіз процесів в освітньому просторі, починаючи 3 другої половини XIX ст., показує, що 3 появою і розвитком масмедіа як з точки зору педагогів-новаторів, в т. ч. періоду СРСР, так i державних структур, виникає життєва необхідність їх використання у навчанні дітей та дорослих 3 метою формування за допомогою медіаосвіти, 3 одного боку, вмінь користуватися відповідними джерелами інформації, a, 3 іншого, насаджувати населенню потрібні владі політикоідеологічні погляди (Коропатник, 2018).

У XXI столітті люди перестали бути лише споживачами інформації, яку транслюють 3MI. Користувачі самі почали створювати контент у медіапросторі: писати дописи у «Фейсбуці», транслювати наживо усе, що відбувається навколо них, завантажувати аматорські відео на «YouTube», які потім використовують 3МI у своїх сюжетах та публікаціях. Це все вказує на те, що суспільство перетворилося на інформаційне - велика частина діяльності та спілкування перемістилася у віртуальний простір. Тому зараз важливою i потрібною $є$ навичка медіаграмотності - критично сприймати інформацію та адекватно використовувати іiї в рамках освітньої діяльності.

Тому ми вважаємо, що необхідно провести серйозне, складне, послідовне i раціональне обговорення проблеми критичного споживання інформації, наскільки це можливо, 3 точки зору на сучасні технології розвитку віртуального інформаційного середовища та умов його використання.

Коли мова заходить про аналіз ролі засобів масової інформації, як розповсюджувачів певних тем, що становлять інтерес, залишається визначити, в якій мірі ці засоби масової інформації $\epsilon$ виключно інструментами інформування про так звані актуальні поточні справи, а в якій мірі вони перебувають на службі споживачів i ïx інтересів, пропонуючи теми більш постійного актуального характеру. Однак парадокс полягає в тому, що сучасні інформаційні агентства, їхні засоби передачі інформації: газети, журнали, радіо-, теле- та інтернет канали орієнтуються не на освітній та соціально корисний зміст наданої інформації, майже не виконують функцію транслятора державних інтересів. Швидше, вони повністю приречені на гонку конкуренції, намагаючись отримати найбільшу кількість передплатників, покупців, споживачів, які готові витрачати свої час, увагу та гроші на продукти, що пропонуються, використовуючи дуже видовищний i успішний контент, орієнтований на рекламу. 3 огляду на той факт, що засоби масової інформації мають таке величезне ідеологічне значення, беззаперечно аудіовізуальна освіта гостро необхідна в школах, тому що ті, хто контролює і працює 3 засобами масової інформації, не тільки мають можливість розставляти пріоритети, давати пояснення і будувати свої власні версії подій, а й мають набагато більшу важливу можливість проектувати ці події як природні і достовірні, просто як частину того, що закономірно відбувається в світі. Це сила міфологізувати, посилювати, перетворювати ситуацію в велику подію або звичайну людину в героя. Факт заповнення або простого опускання інформації стає способом переступити через ідеологію або обрати ідеологію, встати на чиюсь сторону, виділити або підкреслити певну 
опцію. Візьмемо приклад, описаний Леном Мастерманом, засновником сучасної теорії британської медіаосвіти, 3 посиланням на конфлікт на Фолклендських островах, який використовується для ілюстрації того, що ми говорили раніше (Masterman, 1995). У зв'язку з коротким періодом часу, протягом якого відбувалася ця війна, автор вказує на те, що військова ситуація не дозволяла створити тривалу ідеологічну ворожість, як, наприклад, "холодна війна". Навпаки, протягом кількох тижнів необхідно було переконати багатьох порядних і розсудливих людей в тому, що варто віддати своє життя за майбутнє малих островів, про існування яких вони нічого не знали всього кілька тижнів тому. Почуття підтримки, залучення населення у вжиті заходи були обумовлені тим, як це подавали засоби масової інформації. Спочатку було велике несприйняття, але для того, щоб переконати громадськість в праведності справи уряду, потрібна була батарея методів маніпулювання інформацією, не виключаючи брехні, припущень i дезінформації.

В сучасних умовах засоби масової інформації (3МI), незважаючи на суспільну значущість, масовість і доступність, мають величезний вплив на політичні, економічні, культурні та духовні процеси, що відбуваються в суспільстві. Залучаючи громадян до інформаційних відносин, ЗМІ формують певні ціннісно-смислові моделі для засвоєння суспільством i, таким чином, змінюють аксіологічну картину соціуму (Руденко, 2017).

Цей досвід, як і багато інших, які з'являються в засобах масової інформації, привертає нашу увагу i виправдовує необхідність навчання критичному сприйняттю інформації. Освіта повинна сприяти підготовці громадян 3 поточних питань та накопиченню соціальних, культурних та політичних знань (Карпов, 2016). Завдання громадянина - не делегувати свої повноваження, а здійснювати i розвивати їх. Аудіовізуальна освіта - це інструмент, яким володіють викладачі та учні, щоб почати боротьбу з величезною нерівністю в знаннях і силі, яка існує, 3 тими, хто виробляє та постачає інформацію.

Таким чином, наявність освіченості в області комунікації та обробки інформації дасть час i навички для критичного оцінювання медійного контенту і розуміння того, що насправді важливо, актуально, достовірно і може бути засвоєно з точки зору соціальної користі. Постійна присутність засобів масової інформації в соціальному просторі, їх звичний спосіб існування, безсумнівно, привчає користувача до звичного і інтегрованого споживання.

Але, внаслідок роздумів, не тільки час, який ми присвячуємо засобам масової інформації, робить їх значущими; засоби масової інформації $\epsilon$ важливими формувачами нашого сприйняття і ідей, вони - те, що називається, «Компанії Усвідомлення», які надають не тільки інформацію про світ, а й способи побачити і зрозуміти його. Завдання засобів масової інформації полягає у виборчому наданні та побудові знань про суспільство. Тому для того, щоб зрозуміти сенс, мету і інтереси 3МI, необхідно зрозуміти взаємозв'язок між ЗМІ і рекламою.

3 цієї причини сьогодні як ніколи актуально задати собі питання про взаємозв'язок між дискурсами, які просуваються засобами масової інформації, новими технологіями та освітою. Школа i 3MI своїми дискусіями формують громадянськість, суб'єктивність, але 3 абсолютно різних моральних постулатів. Способи мислення, що лежать в основі i просувають різні інформаційні i комунікаційні засоби, не $є$ нейтральними i не зустрічаються в вакуумі; достатньо проаналізувати їх продукти, програми, дизайни. Школа в інформаційному суспільстві повинна, 3 одного боку, пропагувати рефлексивну позицію перед визначеннями та досвідом, які ми отримуємо від засобів масової інформації, а, з іншого боку, створювати простір для роздумів про засоби масової інформації та засвоєння, аналіз і використання їхньої продукції.

Взаємовідносини або зв'язок між засобами масової інформації та освітою - це питання розуміння і пошуку шляху, практики, яка виходить за рамки епізодичних або парадоксальних причин. Вчителям і учням потрібні орієнтири - практичні, відображені i сформульовані навколо процесів побудови освітньої діяльності. 
В даний час значній кількості людей важко вірно зрозуміти повідомлення, що передаються засобами масової інформації. Деконтекстуалізація і фрагментація знань в засобах масової інформації реальність. Разом з тим слід зазначити, що 3 усіма наслідками, що випливають звідси, виникають труднощі, 3 якими стикаються люди зі значним рівнем освіти, навіть в університетах, в плані інтерпретації та осмислення інформації, що надходить до них за різними каналами, які породжують новий тип неписьменності. Наприклад, для розуміння інформації, що передається в телевізійних новинних програмах, потрібен мінімум попередніх знань про найрізноманітніші аспекти. Від історії та географії до національної та зовнішньої політики, моди, літератури, біології та інженерії. Але, перш за все, для цього потрібні знання, які не входять до будьякої конкретної дисципліни як такої, хоча вони вимагають вміння оцінювати, інтерпретувати, розрізняти і кваліфікувати побачене i почуте, щоб мати критерій достовірності про джерела, які нас інформують, і про факти, які ми коментуємо.

Саме тому стає все важче усвідомлювати різницю між інформацією, думкою, вибором того, що $є$ фундаментальним, i тим, що передається, викривати приховані причини або просто вважати, що те, що ми бачимо, має бути виправлено, усунуто i має бути прийнято до уваги . Bce більше і більше існує дистанція, створена засобами масової інформації між тим, що відбувається, і тим, як про це говорять, між реальністю і вигадкою, що, на жаль, часто $\epsilon$ переважаючою в засобах масової інформації. Великий обман полягає в припущенні, що людина, яка збирається використовувати засоби масової інформації, вже має достатню для цього підготовку, що зазвичай не вірно в більшості випадків. Необхідно мати попередні знання або вимоги, отримані в результаті аналізу 3 особистого, культурного i групового досвіду, здатного служити посиланням на те, що приходить до нас із засобів масової інформації.

Зіткнувшись 3 цією дискусією в засобах масової інформації, ми запитуємо себе, яку роль відіграє або може відігравати школа? В першу чергу, школа повинна переосмислити свої функції в новому соціальному контексті, який, крім іншого, характеризується все більш акцентованим переважанням аудіовізуальної культури. Тому, крім передачі інформації, освітня функція сучасної школи повинна бути орієнтована на провокування раціональної організації отриманої фрагментарної інформації. Це повинно стати однією 3 ключових функцій школи в кінці століття: допомагати навчати учнів, тобто самих маленьких громадян, усвідомлювати роль засобів масової інформації в їх власному соціальному житті; знайомити їх 3 технічними і символічними механізмами, за допомогою яких засоби масової інформації спокушають глядача; пропагувати адекватні ціннісні критерії, що вчать учнів бачити i обирати продукти більш високої культурної якості; проливати світло на економічні, політичні та ідеологічні інтереси, які стоять за кожною медіакомпанією та її продуктом.

Власне кажучи, роль освітніх установ полягатимев тому, щоб сприяти формуванню більш освічених, відповідальних і критично налаштованих громадян, оскільки знання $\epsilon$ необхідною умовою для усвідомленого здійснення свободи особистості і повноцінного розвитку демократії. У цьому сенсі, освіта повинна сприяти підготовці громадян 3 поточних питань та формування соціальних, культурних та політичних поглядів.

Bce вищесказане може змусити нас замислитися над тим, що сьогодні функція і завдання шкільної освіти - це не тільки доступ до інформації як такої, і не використання нових технологій або пошук сенсу в освіті як відтворення того, що використовується в суспільстві. Рішення, схоже, полягає не в тому, щоб дозволити собі захопитися впровадженням будь-якої нової інформаційної підтримки в громіздку i розрізнену шкільну програму, а в тому, щоб трансформувати зміст навчання, що, безсумнівно, $\epsilon$ викликом школі як навчальному закладу, що бореться за свій простір, який доведеться розмежувати, переосмислити і захистити перед іншими групами, організаціями і компаніями.

$$
\text { Сьогодні перед школою знову }
$$
стоїть фундаментальне завдання перед 
лицем цієї проблеми, де вона повинна розробити рамки інтерпретації, зміцнення інструментів мислення, що дозволяють учням співставляти i розміщувати інформацію і накопичені знання, визнавати кодекси і мови різних видів знань, вчитися використовувати їх для вираження своїх аргументів і винесення етичних суджень у якості складової частини сучасної освіти.

Школа зобов'язана допомогти учням отримати доступ до освіти в галузі засобів масової інформації, полегшуючи час і простір для обробки, сортування та відтворення відомостей, що надаються засобами масової інформації. Школа як основний постачальник навичок та компетенцій має зайняти позицію штурмана та радника на шляху створення учнем власного освітнього середовища, дати можливість наповнити його змістом, перетворити його в найважливіший інструмент для розуміння і втручання в навколишній світ. Робота 3 інформацією буде складатися 3 побудови 3 учнями схем сприйняття, вираження і реакції на факти, які нам надають засоби масової інформації. У цьому сенсі ми говоримо про критичні прийоми повідомлень, що призводить нас до організації, структурування та інтеграції того, що ми читаємо, i проектуємо в діяльності.

Ці виховні прийоми використання засобів інформації повинні бути відображені в запропонованих навчальних програмах, підготовку яких беруть на себе освітні центри, 3 можливістю для школи як структурного підрозділу освітнього простору визначати на їхній основі власну автономну навчальну програму, де змістіцілі навчання інтегровані, уточнені реальними пропозиціями практичної спрямованості 3 урахуванням територіальних особливостей. У цьому сенсі, розробляємий комплекс заходів повинен сприяти підвищенню рівня діяльності (залучення) різних інформаційних джерел. Зокрема, при здійсненні різних освітніх та виховних заходів буде заохочуватися інтеграція декількох джерел інформації одночасно. Точно так, саме ми повинні ще раз зрозуміти роль вчителя як посередника, так як його участь має значення для створення особистої автономії в побудові навчання, i створенні учнями власного і загального освітнього середовища. Таким чином, ми розуміємо, що вчитель повинен орієнтувати і спрямовувати учнів в цій особистій i прогресивній роботі разом 3 рівнем їх інтересів і досвіду.

Таке розширене бачення ролі інформаційно-комунікаційних засобів дозволяє підняти ряд питань, всі 3 яких пов'язані із взаємовідносинами між цими двома соціальними системами: освітньою або шкільною системою і системою засобів масової інформації, які мають потужний вплив на самовизначення людини в світі. Вплив, який зростає в міру розширення його можливостей i збільшення доступу користувачів 3 індивідуальної, сімейної, формальної та неформальної сфер освіти.

Роль школи фундаментальна, зосереджена на передачі інформації i допомозі учням навчитися шукати необхідну інформацію активно і вибірково, щоб через факти, новини, парадокси i двозначності, які відбуваються в даний час, вони могли дізнатися ступінь важливості й достовірності, яку мають надані відомості. Школа зобов'язана допомогти учневі отримати освітні навички в галузі користування засобами масової інформації, щоб оптимізувати час та зусилля на пошук, обробку та засвоєння знань, які з них можна отримати. Робота 3 інформацією буде полягати в тому, щоб надати учням схеми, що дозволяють сприймати, сортувати, оцінювати і реагувати на факти, надані засобами масової інформації.

Навчальні матеріали надані школою і представлені у ЗМІ необхідно представляти не тільки на очних заняттях у класі, а й у вигляді цікавого та динамічного контенту у віртуальному просторі, щоб відкрити численні шляхи i можливості зв'язку iз соціальною діяльністю учнів. Отже, школа в інформаційному суспільстві повинна, 3 одного боку, просувати рефлексивну позицію стосовно до знань, які ми отримуємо від засобів масової інформації, i, 3 іншого боку, створювати простір для роздумів про засоби масової інформації i засвоєння та відтворення їх продуктів.

У тому ж сенсі видається очевидним, що будь-яка дія, спосіб здійснення практичної або проективної діяльності в 
галузі моделювання навчальних програм, які кожен освітній центр передбачає, має грунтуватися на розумінні сучасних аспектів виховної та освітньої діяльності, які зараз неможливо відокремити від світового інформаційного середовища. Тому питання взаємин або зв'язку між ЗМІ та освітою - це питання розуміння i пошуку шляху, практики, яка виходить за рамки епізодичних або парадоксальних причин. Вчителям потрібні орієнтири, практичні відображення, комплексні схеми і побудови освітнього процесу, сформульовані 3 урахуванням ролі сучасного інформаційного середовища i засобів масової інформації, як основних важелів його впливу на формування особистості учня та його навчальних здібностей.

\section{Висновки}

До залучення засобів масової інформації у освітній процес слід підходити з точки зору зв'язку інформаційних матеріалів, ресурсів, сучасних технологій навчання 3 класичною практикою викладання, що вписується в етичний варіант - не відриватися від шкільного проекту, профільованого в соціально-культурному контексті, систематично розмірковуючи про його макро-структурні детермінанти, в той же час, проектуючи звідти поглиблену роботу над тим, чому саме надає значення навчальний заклад.
Не викликає сумніву необхідність у вихованні зростаючого покоління, здатного критично оцінювати отриману інформацію, що володіє своєрідним критичним імунітетом до потенційних маніпуляцій свідомістю.

Вивчення засобів масової інформації повинно бути частиною освітнього процесу в кожному навчальному закладі 3 урахуванням потенційно рівноцінного значення як використання матеріалів 3МI під час класних занять, так i вивчення окремих видів медіа, навчання створенню власного медіа контенту.

Використання матеріалів засобів масової інформації під час здійснення виховної діяльності надає додаткові можливості для формування активної громадянської позиції, патріотичного виховання молоді в сучасній етнокультурній ситуації.

Комплексність та різнобічність сучасної культури актуалізують пошук оптимального варіанту організації освітнього середовища для створення освітнього простору в рамках окремого навчального закладу 3 урахуванням інформаційного поля ЗМІ.

Для формування сучасної соціально компетентної особистості з високим рівнем культури та громадянської відповідальності потрібно об'єднання зусиль не тільки професійних педагогів, а й спеціалістів мас-медіа, громадських організацій, батьків i, звичайно, самих учнів.

\section{БІБЛІОГРАФІЧНІ ПОСИЛАННЯ}

Винтерхофф-Шпурк П. Медиапсихология. Основные принципы: пер. с нем. 2-е изд. испр. перераб. и доп. Харьков, 2016. 268 с.

За результатами щорічного опитування «Ставлення населення до ЗМІ та споживання різних типів 3МI у 2018 р.», здійсненого соціологічною компанією InMind на замовлення міжнародної громадської організації Internews, що реалізує програму «Український медійний проект», за фінансової підтримки Агенції США 3 міжнародного розвитку (USAID). Режим доступу: URL: https://internews.in.ua/uk/news/dovira-do-zmi-v-ukrajinizrostaje-nove-

Карпов А.О. Социализация научно-исследовательского типа в обществе знаний. Современное образование. 2016. № 1. C. 1-35.

Коропатник М. Медіаосвіта на вітчизняних теренах: досвід минулого для уроків сьогодення. Роль медіа у формуванні навичок медіаграмотності у споживачів інформації: збірник статей Шостої міжнародної науковометодичної конференції «Практична медіаграмотність: міжнародний досвід та українські перспективи». Київ: Центр Вільної Преси, Академія української преси, 2018. с.27-36. URL: https://medialiteracy.org.ua/rol-media-uformuvanni-navychok-mediagramotnosti-u-spozhyvachiv-informatsiyi/

Ладика I. Роль медіа у формуванні навичок медіаграмотності у споживачів інформації: збірник статей Шостої міжнародної науково-методичної конференції «Практична медіаграмотність: міжнародний досвід та українські перспективи». Київ: Центр Вільної Преси, Академія української преси, 2018. С. 36-40. URL: https:// medialiteracy.org.ua/rol-media-u-formuvanni-navychok-mediagramotnosti-u-spozhyvachiv-informatsiyi/

Нерсесян Г. А. Медіаграмотність молоді - запорука протидії інформаційній агресії. Інвестиції: практика та досвід. 2018. № 6. С. 56-60.

Пєнзєв А.Є. Вплив жорстоких комп’ютерних ігор на людину. Вісник ХНУ ім. В.Н. Каразіна. Серія «Теорія культури і філософія науки». 2012. №1029-I. URL: https://periodicals.karazin.ua/thcphs/article/view/1953/1884 www.grani.org.ua 
Руденко А.М. Воздействие средств массовой коммуникации на современное общество. Медиаобразование. Media Education. 2017. № 3. C. 134-142.

Swartz, T., Hatcher, T. Virtual Experience: The Impact of Mediated Communication in a Democratic Society Educational. Technology. 1996. Vol. 36. No. 6. P.133-137.

Masterman, L. Media Education Worldwide: Objectives, Values and Superhighways. Media Development. 1995. № 2. Vol. XLII. PP. 6-9.

\title{
REFERENCES
}

Karpov,A.O.(2016) Sotsializatsija nauchno-issledovatelskogo tipa v obschestve znanij. Sovremennoe obrazovanie. № 1. pp. 1-35.

Koropatnik, M. (2018) Mediaosvita na vitchiznjanix terenah: dosvif mynulogo dlja urokiv sjogodennja. Rol mrdia u formuvanni navychok mediagramotnosti u spozhivachiv informatsiji: zbirnyk starey Schostoji mizhnarodnoji naukovo-mdtodychnoji konferentsiji "Praktychna mediagramotnist: mizhnarodnij dosvid ta ukrajnski perspektyvy". Kyiv: Tsentr Vilnoji Presy, Akademija ukrajnskoji presy. pp. 27-36. URL: https://medialiteracy.org.ua/rol-media-uformuvanni-navychok-mediagramotnosti-u-spozhyvachiv-informatsiyi/

Ladyka I. (2018) Rol media u formuvanni navichok mediagramotnosti u spozhivachiv informatsiji: zbirnyk statey Schostoji mizhnarodnoji naukovo-metodychnoji konferentsiji "Praktychna mediagramotnist: mizhnarodnyj dosvid ta ukrajnski perspektyvy". Kyiv: Tsentr vilnoji Presy, Akademija ukrajnskoji presy. S. 36-40. URL: https://medialiteracy. org.ua/rol-media-u-formuvanni-navychok-mediagramotnosti-u-spozhyvachiv-informatsiyi/

Masterman, L. (1995) Media Education Worldwide: Objectives, Values and Superhighways. Media Development. № 2. Vol. XLII. pp. 6-9.

Nersesjan, G.A. (2018) Mediagramotnost molodi - zaporuka protydiji informatsijnij agressiji. Investystiji: praktyka ta dosvid. № 6. pp. 56-60.

Penzev, A.E. (2012) Vplyv zhorstokix kompjuternix igor na ljudynu. Vidnil KhMU im. V.N. Karazina Serija " Teorija kultiri i philosophii nauki". №1029-I. URL: https://periodicals.karazin.ua/thcphs/article/view/1953/1884

Rudenko, A.M. (2017) Vozdejstvije sredstv massovoj kommunikatsiji na sovremennoe obschestvo. Mediaobrazovanie. Media education № 3. pp. 134-142.

Swartz, T., Hatcher, T. (1996) Virtual Experience: The Impact of Mediated Communication in a Democratic Society Educational. Technology. Vol. 36. No. 6. pp.133-137.

Vinterhoff-Schpurk, P. Mediapsixologija. (2016) Osnovnie printsipi: per. s nem. 2-e izd., ispr. perersb. i dop. Kharkov. 268 p.

Za rezultatami schorichnogo opytuvannja "Stavlennja naselennja do ZMI to spozhivannja riznix typic ZMI u 2018 r.", znisnenogo sotsiologichnoju konpanieju InMind na zamovlennja mizhnarodnoji gromadsjkoji organizatsiji Internews, scho realizue programu "Ukrajinskij medijnij projekt", za finantsovoji pidtrymki Agentsii SShA z mizhnarodnogo rozvytku (USAID). Rezhym dostupu: URL: https://internews.in.ua/uk/news/dovira-do-zmi-vukrajini-zrostaje-nove-

\author{
Grigorov George \\ Ph.D., https://orcid.org// 0000-0001-7395-273X, GeorgyGrigorov@gmail.com
}

Стаття надійшла / Article arrived: 01.03.2021

Схвалено до друку / Accepted: 17.04.2021 